\title{
International Taxation and Environmental Protection
}

(Final version published as: Alice Pirlot, "Chapter 15. International taxation and environmental protection", in: Yariv Brauner (ed.), Research Handbook on International Taxation (Edward Elgar 2020), pp. 258-277).

Alice Pirlot*

Building upon the existing literature, this Chapter shows that international tax law might have either positive or negative effects on the protection of the environment. First, this Chapter discusses the positive effects that international tax law could have on environmental protection if global environmental taxes were to be adopted. Second, by means of three concrete examples, this chapter analyzes three types of negative effects that international tax provisions might have on environmental protection. The international tax provisions that apply to the aviation sector are used as a first example to show that international tax law can cause a country's tax system to be or remain disconnected from or inconsistent with its environmental policy agenda, which is problematic. Then, the case of environmental border tax adjustments is used to show how international tax provisions are sometimes used as an argument against the adoption of innovative domestic or regional tax measures that would allegedly help foster environmental protection. Finally, a third potential negative effect of international tax law on environmental protection is discussed through the example of emissions trading schemes, to highlight how double tax treaties might affect their effectiveness. This Chapter concludes that the interactions between international tax law and environmental protection need to be acknowledged and that coordination is key to ensure that international tax law does not undermine the legislator's efforts to protect the environment.

\section{INTRODUCTION}

Legal scholars have analyzed the potential conflicts and interactions between environmental law and different branches of international public law, in particular those between environmental law and international trade law and human rights law. ${ }^{1}$ Their analysis contributes to the understanding of how provisions that are not directly targeted at environmental protection can either support or undermine the efforts of the legislator to protect the environment. So far, however, scholars have not paid much attention to the positive and negative effects that international tax law can have on environmental policies and, more generally, on the protection of the environment. Research on the linkages between environmental protection and tax law has mostly focused on how domestic-

\footnotetext{
* Research fellow (law) at the Oxford University Centre for Business Taxation (Alice.Pirlot@ sbs.ox.ac.uk); FNRS research fellow at the Université catholique Louvain (currently on hold). I would like to thank Professor Yariv Brauner, Elena Masseglia Miszczyszyn, Professor Edoardo Traversa, Fanny Vanrykel for their helpful comments on earlier drafts. Many thanks as well to my colleagues at the Centre for Business Taxation and Professor Aitor Navarro Ibarrola. Finally, special thanks go to Professor Roland Ismer for providing me with the opportunity to discuss this topic in a stimulating and friendly academic environment as well as to Sophia Piotrowski. The usual disclaimers apply.

1. See for example, Alan Boyle, 'Relationship Between International Environmental Law and Other Branches of International Law' in Daniel Bodansky, Jutta Brunnée, and Ellen Hey (eds), Relationship Between International Law and Other Branches of International Law (OUP, 2008) 125-47. See also Gabrielle Marceau, 'Conflicts of Norms and Conflicts of Jurisdictions. The Relationship between the WTO Agreement and MEAs and other Treaties' (2001) 35(6) Journal of World Trade 1081-131; Ved Nanda and George Pring, International Environmental Law and Policy for the 21st Century: 2nd Revised Edition (Martinus Nijhoff Publishers, 2013), in particular chapters 14 (on International Trade and the Environment) and 15 (on The Environment and Human Rights).
} 
rather than international - tax law can integrate environmental considerations. ${ }^{2}$ Only a few authors have looked at how international taxation can impact environmental regulations-such as emissions trading schemes-and vice versa. To the best of our knowledge, there is no comprehensive study that provides an overview of the main issues that arise when international tax law interacts with domestic, regional, or international environmental regulations. Similarly, not much has been said in the literature on how international tax law has had — or might have - an impact on environmental protection at the domestic, regional, and global levels.

Building upon the existing literature, this Chapter shows that international tax law might have either positive or negative effects on the protection of the environment. This analysis could later serve as a basis to further develop this field of research and better understand how international tax law can support - rather than undermine - the development of meaningful environmental practices and standards.

In this Chapter, international tax law is defined in a broad sense and is taken to include double tax treaties, the OECD Model Tax Convention on Income and Capital, the U.N. Model Double Taxation Convention between developed and developing countries but also tax-related provisions in non-tax-specific international agreements, such as the WTO law agreements. This Chapter does not discuss any of these instruments in details; the objective is primarily to highlight their potential impact on the protection of the environment. Regarding non-tax specific international agreements, this Chapter focuses on the agreements that have previously been discussed in the literature as obstacles to the adoption of environmental taxes. These agreements include the Kyoto Protocol, the Chicago Convention, the General Agreement on Tariffs and Trade (GATT), and the Agreement on Subsidies and Countervailing Measures (ASCM). Tax-related provisions in other international agreements, such as bilateral investment treaties, could also have a negative environmental impact but they are not discussed here as their effects on environmental protection are less straightforward.

This Chapter is structured around four main sections, which correspond to four types of effects that international tax law might have on environmental protection. Given that the literature has focused on climate change, most of the sections are illustrated by examples of market-based climate mitigation policy instruments. Nevertheless, most of the legal conclusions drawn in this Chapter could apply to other global and cross-border environmental issues, such as biodiversity loss or water pollution. ${ }^{3}$

Section II discusses the positive effects that international tax law could have on environmental protection if global environmental taxes were adopted. In other words, this section highlights that international tax law could be an instrument to pursue environmental goals. This section analyzes the advantages of global environmental taxes in comparison to domestic environmental instruments and the obstacles to their adoption. It does not elaborate on the definition and role of environmental taxes. These questions do not, as such, amount to international legal issues and they have already been extensively addressed in the scholarship. ${ }^{4}$

\footnotetext{
2.The following books provide a very good overview of the topics that have been addressed by legal scholars: Janet E. Milne (ed.), Environmental Taxation and the Law (Edward Elgar Publishing, 2017); Janet E. Milne and Mikael Skou Andersen (eds), Handbook of Research on Environmental Taxation (Edward Elgar Publishing, 2012). See also Edward Elgar Publishing's Critical Issues in Environmental Taxation book series.

3. On the definition of global versus national and cross-border environmental issues, see Alice Pirlot, Environmental Border Tax Adjustments and International Trade Law (Edward Elgar Publishing, 2017) 92-94.

4. See the books mentioned supra note 2 .
} 
Sections III, $I V$, and $V$ then focus on the potential negative effects of international tax provisions on the adoption and implementation of domestic environmental taxes and domestic and/or regional market-based instruments as alternative solutions to mitigate global environmental issues.

Section III uses the taxation of the aviation sector as an example to underline that international tax law can cause a country's tax system to be or remain disconnected from or be inconsistent with its environmental policy agenda, which is problematic. Indeed, some international tax provisions might prevent, or make it more complicated, for countries to align their tax system-designed before the need to protect the environment had been recognized-with environmental concerns.

Section IV then discusses the example of environmental border tax adjustments (BTAs) to illustrate how international tax provisions are sometimes used as an argument against the adoption of innovative domestic or regional tax measures that could help foster environmental protection.

Finally, Section $V$ discusses a third potential negative effect of international tax law on environmental protection, namely the impact that double tax treaties might have on the effectiveness of environmental (non-fiscal) market-based regulations, in particular emissions trading schemes. This last section draws attention to the need for countries to anticipate the international tax consequences of environmental economic instruments that involve cross-border components.

\section{INTERNATIONAL TAX LAW AS AN INSTRUMENT OF ENVIRONMENTAL PROTECTION: THE CASE OF GLOBAL ENVIRONMENTAL TAXES}

No global environmental tax has been adopted so far, which makes it impossible to empirically assess the effects of such a tax on environmental protection. One can nevertheless assume that, if countries were to adopt a global environmental tax, such as a global carbon tax, the effects on the environment would be positive. The environmental costs of pollution, for example greenhouse gas (GHG) emissions, would be internalized through a global tax instrument, which would discourage polluting behaviors and encourage investment in more climate friendly technologies all over the world.

These taxes have been discussed both in the academic literature and, to a more limited extent, in various proposals and recommendations issued by international organizations. ${ }^{5}$ The authors

5.See among others, Ruwantissa Abeyratne, 'The Proposed Global Fuel Tax on Aviation' (2011) 41(6) Environmental Policy and Law, 273-279; Iñaki Bilbao Estrada and Pasquale Pistone, 'Global CO2 Taxes' (2013) 41(1) Intertax 2-14; Tatiana Falcão, A Proposition for a Multilateral Carbon Tax Treaty (IBFD, 2019) 1; Parthasarathi Shome, 'A 21st Century Global Carbon Tax' (1996) 50 (11/12) Bulletin for International Fiscal Documentation 481-89. There seems to be more economic research than legal research on this topic. See David Bicchetti, Laurent Drouet, Philippe Thalmann and Marc Vielle, 'The Feasibility of a World-Wide Tax on Anthropogenic Emissions of Greenhouse Gases: Levels and Impacts of World-Wide Taxes on Greenhouse Gases' (2007) 04 Research Paper, NCCR Climate, Universität Bern, EPA, Paul Scherrer Institut; Javier Cuervo and Ved P. Gandhi, 'Carbon Taxes: Their Macroeconomic Effects and Prospects for Global Adoption-A Survey of the Literature' (1998) IMF Working Paper; Michael Hoel, 'Harmonization of Carbon Taxes in International Climate Agreements' (1993) 3 Environmental and Resource Economics 221-31; Michael Hoel, 'Carbon Taxes: An International Tax or Harmonized Domestic Taxes?' (1992) 36(2) European Economic Review 400; David M. McEvoy and Matthew McGinty, 'Negotiating a Uniform Emissions Tax in International Environmental Agreements' (2018) 90 Journal of Environmental Economics and Management 217-31. See also the Zedillo report: U.N. General Assembly, High-Level International Intergovernmental Consideration of Financing for Development, 26 June 2001, 55th session, A/55/1000, Executive Summary of the Report of the High-level Panel on Financing for Development, for a "Global Carbon Tax" 26- 27; U.N. Framework Convention on Climate Change, Conference of the Parties serving as the meeting of the parties to the Kyoto Protocol, 2nd session, Nairobi, 6-17 November 2006, FCCC/KP/CMP/2006/10, para. 110 (statement by the 
generally assert that international instruments are the first and best option for tackling global problems, because of their advantages in comparison to domestic or regional instruments. By definition, a global environmental tax allows internalization of the environmental costs generated over a significant number of countries while avoiding any distortive effects on cross-border trade. In contrast, local, national and regional environmental taxes-and, more generally, any local, national and regional environmental market-based measures - usually have limited territorial scope, which makes it more difficult to tackle cross-border and global environmental problems. Moreover, domestic and regional action presents certain risks, both from a trade and tax perspectives. ${ }^{6}$

First, domestic and regional environmental policies can affect competitiveness in the implementing country, leading domestic enterprises to relocate to pollution havens, namely jurisdictions with low environmental standards (which is usually referred to as "carbon leakage" in the climate context). In the worst-case scenario, pollution leakage will lead to a higher level of pollution at the global level. Moreover, domestic environmental actions also present the disadvantage of reducing the implementing country's leverage in international environmental negotiations. In economic terms, this limit to domestic environmental policies has been analyzed as a free-riding problem. ${ }^{7}$ Roughly speaking, this suggests that environmental action undertaken by one country may benefit the rest of the world but does not encourage other countries to follow-suit.

Second, the non-coordinated adoption of environmental taxes can lead to double taxation and double-non-taxation, which might affect the effectiveness of environmental taxes by altering the price signal that they aim to set. ${ }^{8}$ Let us assume that a country ('country A') adopts a carbon tax on the consumption of energy products. This tax is designed in such a way that the tax burden reflects the GHG emissions intensity of each energy product (for example, coal is subject to a higher tax burden than gas because coal's emissions factor is higher). Now, let us assume that an exporting country ('country B'), which is the country of extraction, has an energy tax that applies only to gas at the point of extraction. In the absence of any mechanism to relieve the imported gas of the double carbon and energy tax, the price signal that 'country A' intended to create by means of its carbon tax would be distorted. This distortion could make the environmental tax ineffective (for example, if the double tax on gas encourages consumers to consume coal rather than gas).

Consequently, countries might consider designing environmental taxes, the main objective of which is to introduce a price signal, in such a way so as to ensure that the tax burden is proportionate to the net level of environmental costs, taking into account the level (or lack) of internalisation that has taken place abroad. If environmental costs have been internalized in other countries, this should, ideally, be acknowledged. In theory, it is suboptimal to disregard whether and how the pollution associated with imported products has already been internalized in the country(ies) of production. In practice, an ideal design would require assessment of the quality and level of internalization policies of third countries, which is extremely difficult without coordination at the

President of the Swiss Confederation).

6..Please note that this and the next paragraphs are inspired by my book, Pirlot, supra note 3 (section 1 of the introduction), which is why no extensive footnotes is being used here. On the general (non-environmental specific) advantages of "global cooperation and coordination of tax matters," see Yariv Brauner, 'An International Tax Regime in Crystallization' (2003) 56 Tax Law Review 259-328.

7. See William Nordhaus, 'Climate Clubs: Overcoming Free-riding in International Climate Policy' (2015) 105(4) American Economic Review 1339-70.

8. This design issue is mentioned in United Nations, Committee of Experts on International Cooperation in Tax Matters, Seventeenth Session, Environmental tax issues, Note by the Secretariat, 2 October 2018, E/C.18/2018/CRP.14, at 8, point VIII.v. 
international level. Let us assume that country B's energy tax is a $\$ 60$ tax per ton of $\mathrm{CO}_{2}$ emissions and country A's carbon tax is a $\$ 50$ tax per ton of $\mathrm{CO}_{2}$ emissions. Should the gas imported from country B to country A be exempted from the carbon tax in country A? What if country A does not have enough information to assess the level of internalization that has taken place in country B? Let us now assume that another country ('country $\mathrm{C}$ ') also adopts a carbon tax (e.g., a $\$ 40$ per ton of $\mathrm{CO}_{2}$ emissions). Should country $\mathrm{A}$ account for the difference in the tax burden and tax the imported gas from country $\mathrm{C}$ at a $\$ 10$ tax per ton of $\mathrm{CO}_{2}$ emissions? If so, could country $\mathrm{C}$ challenge the tax imposed by country $\mathrm{A}$ on the ground that the tax is extraterritorial or discriminatory? ${ }^{9}$ What if country $\mathrm{C}$ does not have a tax on $\mathrm{CO}_{2}$ emissions but requires gas companies to plant trees to compensate for the carbon intensity of the gas they sell?

These questions highlight the complexity that characterizes the design of optimal environmental taxes at the national or regional level in the context of a global economy. Therefore, these questions provide arguments in support of coordinated action to tackle global environmental issues. Coordinated action would allow the setting of a common price signal for the costs associated with pollution, which would reduce, if not eliminate, the risks of loss of competitiveness, pollution leakage, double and double-non-taxation linked to the adoption of domestic environmental taxes. ${ }^{10}$ Yet, despite their clear advantages in comparison to unilateral environmental measures, global environmental taxes are unlikely to be adopted in the near future. ${ }^{11}$ As pointed out by Vanistendael, proposals in favor of global environmental taxes differ from the direct tax issues that are traditionally dealt with in international tax treaties and do not imply the adoption of international taxes. ${ }^{12}$ The negotiation of global environmental taxes would require countries to determine where pollution needs to be internalized (in the production or the consumption country, or both), agree on a common tax rate (or a threshold or range of tax rates), find mechanisms to neutralize the potential negative regressive effects of the tax (within and between countries), and define to what extent the tax should be harmonized (full versus limited tax harmonisation). ${ }^{13}$ These tax design elements, which are necessary for the introduction of a global environmental tax, are likely to divide countries. Hence, such taxes do not appear as a politically feasible solution at the moment. There is scope, however, for more limited international cooperation. Indeed, international environmental and tax law could be brought closer together, if not through the adoption of global environmental taxes, then maybe through international coordination of best practices in terms of environmental taxes and tax incentives. ${ }^{44}$ For example, one could explore the option of negotiating

9. Infra Section IV. On the concepts of extraterritoriality and territorial extension in the context of environmental tax measures, see Alice Pirlot, 'Environmental Border Tax Adjustments (BTAs)' in Jan De Bruyne, Michaël de Potter de ten Broeck and Isabelle Van Hiel (eds), Policy Within and Through Law (Maklu, 2015), 107-19.

10. On the benefits of a minimum international carbon price, see Martin L. Weitzman, 'On a World Climate Assembly and the Social Cost of Carbon' (2017) 84 Economica 559-86. See also IMF, Fiscal Monitor, 'How to Mitigate Climate Change,' October 2019, available at https://www.imf.org/en/Publications/FM/Issues/2019/09/12/fiscal-monitor-october-2019 [hereinafter IMF, Fiscal Monitor]. In this Report on "How to Mitigate Climate Change," the IMF indicated that an international carbon price floor could help mitigate climate change.

11. See, e.g., Bilbao Estrada and Pistone, supra note 5, at 8-10, § 4, Cuervo and Gandhi, supra note 5.

12. Frans Vanistendael, 'Chapter 10: Global Law and the Search for Constitutional Pluralism' in Georg W. Kofler, Miguel Poiares Maduro and Pasquale Pistone (eds), Human Rights and Taxation in Europe and the World (IBFD, 2011), available at Online Books IBFD (last accessed 28 Aug. 2019), § 10.3.1. See also Falcão, supra note 5, at 3-4. See, however, the International Fuel Tax Agreement between Canadian provinces and American states.

13. Different models of international environmental taxes have been discussed in the scholarship. See Philippe Thalmann, 'Global Environmental Taxes' in Janet E. Milne and Mikael Skou Andersen (eds), Handbook of Research on Environmental Taxation (Edward Elgar Publishing, 2012), 456-76; Igor Bashmakov et al., Chapter 6. Policies, Measures, and Instruments, II 6.3.4.2., at 430, available at http://unfccc.int/resource/cd_roms/na1/mitigation/Resource_ materials/IPCC_WG3_TAR_Mitigation_2001/Chapter_6.pdf.

14. This question is similar to the one that has been asked by Brauner with regard to the interactions between tax and trade law. Yariv Brauner, 'International Trade and Tax Agreements May be Coordinated, But Not Reconciled' (2005) 25 Virginia Tax Review 
an international model for environmental taxation. ${ }^{15}$ Although the U.N. Committee of Experts on International Cooperation in Tax Matters, the IMF and the World Bank have, so far, concentrated their efforts on providing policy-makers with recommendations on the design of domestic carbon taxes, these recommendations could pave the way towards the adoption of internationally harmonized carbon taxes. ${ }^{16}$

\section{INTERNATIONAL TAX LAW AS A POTENTIAL CAUSE FOR THE LACK OF CONSISTENCY BETWEEN DOMESTIC TAX AND ENVIRONMENTAL POLICIES: THE CASE OF THE AVIATION SECTOR}

As an alternative to global climate action, some countries have introduced, on a unilateral basis, carbon taxes at the domestic level. ${ }^{17}$ These taxes are the next-best option for curbing GHG emissions. Although countries are in principle free to adopt any type of taxes that they deem useful to protect the environment, they face, in certain circumstances, international legal obstacles that limit their tax sovereignty. The objective of this section is to illustrate how these legal obstacles might shape tax systems in a way that is disconnected from environmental concerns and possibly inconsistent with countries' own environmental policy agendas. This section analyzes these legal obstacles by focusing on one concrete example, namely the taxation of the aviation sector.

This section discusses the existing international tax provisions that apply to the aviation sector and assesses their potential impact on the environment, underlining that these provisions were adopted in the 20th century, at a time when the impact of the aviation sector on the environment had not been acknowledged as it is today.

First, some tax provisions in international agreements put limits on the adoption of taxes on aviation fuels, which might prevent countries from using their domestic tax system to internalize some of the environmental costs generated by the aviation sector. ${ }^{18}$ Second, double tax treaties include specific provisions that grant taxing rights on the profits of international air transport to the country of residence. ${ }^{19}$ These provisions might give the sector a direct relative price advantage in comparison to other transport sectors. Indeed, no other sector benefits from a similar legal regime, except for the shipping sector to a limited extent. ${ }^{20}$ Therefore, one could consider that the

251-311. On whether environmental considerations could be integrated into double tax treaties, see Alice Pirlot, 'Towards 'Green' Transfer Pricing: Including Environmental Parameters in Transfer Pricing Rules' in Lee Soocheol et al. (eds), Environmental Taxation and Green Fiscal Reform Theory and Impact (Critical Issues in Environmental Taxation Series, Edward Elgar Publishing, 2014) 98-110.

15. In that respect, see Cuervo and Gandhi; Falcão, supra note 5.

16. See Committee of Experts on International Cooperation in Tax Matters, Environmental Tax Issues, 19th Session, 15-18 October 2019, 27 September 2019, E/C.18/2019/CRP.23; IMF, Fiscal Monitor, supra note 10; World Bank Group, 'Carbon Tax Guide. A Handbook for Policy Makers' March 2017, available at https://openknowledge.worldbank.org/bitstream/handle/10986/ 26300/Carbon\%20Tax\%20Guide\%20-\%20Main\%20Report\%20web\%20FINAL.pdf?sequence= 1\&isAllowed=y. See also the reference to environmental taxes and the Paris Agreement in United Nations, Economic and Social Council, Committee of Experts on International Cooperation in Tax Matters, 17-20 October 2017, Environmental Tax Issues of Relevance to Developing Countries, Update on Environmental Taxation, Note by the Secretariat, 8 August 2018, E/C.18/2017/5, para. 12 [hereinafter Environmental Tax Issues of Relevance to Developing Countries].

17. See World Bank Group, 'State and Trends of Carbon Pricing 2018, available at https://openknowledge. worldbank.org/bitstream/handle/10986/29687/9781464812927.pdf?sequence=5\&isAllowed=y.

18. See infra Section III.A.

19. See infra Section III.B.

20. For this reason, section III.B also contains a few references to the shipping sector. On the similarities and differences between the aviation and shipping sector, see IMF \& World Bank, "Market-Based Instruments for International Aviation and Shipping as a Source of Climate Finance", Background Paper for the Report to the G20 on "Mobilizing Sources of Climate Finance", November 
international tax system favors the aviation sector in comparison to other transport sector, which, allegedly, could lead to unintended negative environmental consequences.

\section{A. Taxes on Aviation Fuel: The Chicago Convention, International Civil Aviation Organization Non-Binding Resolutions and the Kyoto Protocol}

The Chicago Convention on International Civil Aviation was first adopted in December 1944 and later amended. ${ }^{21}$ It has a broad membership with 193 parties and its objective is to establish certain principles and arrangements that provide for a "safe and orderly" environment supporting the development of international civil aviation. ${ }^{22}$ Although the Chicago Convention is not an international tax agreement, it includes two provisions that regulate tax matters: Articles 15 and 24. These provisions are not specifically targeted at environmental taxes but they do generally regulate the types of taxes that countries are allowed to impose on civil aviation.

Article 15 prevents members to adopt "fees, dues or other charges (...) in respect solely of the right of transit over or entry into or exit from its territory of any aircraft of a contracting State or persons of property thereon." 23 Article 24 prevents signatories from imposing taxes on "fuel, lubricating oils, spare parts, regular equipment and aircraft stores on board an aircraft of a contracting State, on arrival in the territory of another contracting State and retained on board on leaving the territory of that State." ${ }^{24}$ Article 24 does not prevent signatories of the Chicago Convention from taxing fuel that is loaded into aircrafts on their territory. But other bilateral agreements do. For example, the U.S. Model Open Skies Agreement, which was used as a basis to negotiate air transport agreements between the United States and other countries, requires that fuel be exempted when it is "introduced into or supplied in the territory of a Party for use in an aircraft of an airline of the other Party engaged in international air transportation (. . .)." ${ }^{25}$ In the absence of such provisions, countries remain free to adopt taxes on fuels loaded into aircraft on their territory. ${ }^{26}$ However, they are discouraged from doing so because air carriers can easily avoid such taxes by systematically fuelling their tanks in jurisdictions where no tax is imposed on aviation fuel. Unless all states unanimously adopt taxes on fuels, these taxes are most likely to be ineffective. ${ }^{27}$

In addition to the Chicago Convention, members of the International Civil Aviation Organization (ICAO) are encouraged to follow recommendations on the taxation of the aviation sector that go beyond the requirements laid down in the Chicago Convention. First, the Council resolution on taxation of international air transport recommends that states exempt fuel, lubricants and other

2011, disponible via https://www.imf.org/external/np/g20/pdf/110411a.pdf.

21. All the documents related to the Chicago Convention can be found on the following webpage: https://www.icao.int/publications/pages/doc7300.aspx.

22. Preamble of the Chicago Convention.

23.Article 15, last paragraph. Note that the English version differs from the French and Spanish versions, which include a clear reference to "taxes" and "impuestos".

24.Article 24(a) of the Chicago Convention.

25.Article 9, para. 2(c) of the Model Open Skies Agreement, 12 January 2012.

26.For an overview of domestic carbon taxes on aviation fuels, but also distance-based air passenger taxes, 'frequent flyer levy' and other climate policies on the aviation sector, see Jörgen Larsson, Anna Elofsson, Thomas Sterner and Jonas Åkerman, 'International and National Climate Policies for Aviation: A Review' (2019) 19(6) Climate Policy, 787-99.

27. See Michael Keen and Jon Strand, 'Indirect Taxes on International Aviation' IMF Working Paper, WP/06/124, at 29-30. See also Michael Keen, Ian Parry and Jon Strand, 'Planes, Ships and Taxes: Charging for International Aviation and Maritime Emissions' (2013) 28(76) Economic Policy, 701-49. As rightly noted by Larsson et al., supra note 26, countries could also proceed by means of bilateral Air Service Agreements (p. 792), which would not only reduce the risks of loss of competitiveness but would also allow countries to override article 24 of the Chicago Convention for the aircraft from the bilateral partners. 
consumable technical supplies such as hydraulic and cooling fluids from taxation. ${ }^{28}$ As explained in the commentary on this ICAO Council resolution, this recommendation is even more generous to the aviation sector than Article 24 of the Chicago Convention as it encourages Member States to grant the exemption regardless of the fact that the fuel, lubricants, and other consumable technical supplies are "retained on board or leaving the territory." ${ }^{29}$ Second, the Council resolution on taxation of international air transport encourages to eliminate "all forms of taxation on the sale or use of international transport by air, including taxes on gross receipts of operators and taxes levied directly on passengers or shippers." 30

These recommendations might appear a little outdated in today's context where some states are trying to internalize the GHG of the aviation sector, including through tax instruments. ${ }^{31}$ It is clear that the justifications underlying the ICAO's policies on taxation in the field of international air transport were fully disconnected from environmental consideration. The ICAO's main objective was to limit the tax burden on the aviation sector so as to permit the development of air transport. ${ }^{32}$ For example, taxes levied on gross receipts of international air carriers were considered undesirable due to their deterrent effects. ${ }^{33}$ Since such taxes could have been passed on to consumers, they could have led to a decrease in the public's use of air transport, which was considered to be a negative outcome. ${ }^{34}$ Now that the need to tackle climate change has been widely recognized, it is unlikely that such an outcome would still be considered undesirable. ${ }^{35}$

More and more of its member states have notified the ICAO that they are willing to adopt economic instruments to internalize the climate impact of the aviation sector. ${ }^{36}$ For example, France has made clear that it is supportive of "international action to tackle the effects of aviation on climate change through the application of market-based measures." ${ }^{37}$ Austria, Iceland, the United Kingdom, the Netherlands, and Switzerland have also expressed their support for market-based measures in order to mitigate the environmental impact of aviation. ${ }^{38}$ The United Kingdom has gone even further, considering that "where countries choose to apply aviation duties, international rules should not prevent ICAO members from structuring duties in ways that incentivize more efficient and less

28. See ICAO's Policies on Taxation in the Field of International Air Transport, Council Resolution on Taxation of International Air Transport, Approved by the Council on 24 February 1999, 3rd edn (2000), Doc. 8632, para. 1 [hereinafter ICAO's Policies on Taxation in the Field of International Air Transport],

29. ICAO's Policies on Taxation in the Field of International Air Transport, Commentary on Council Resolution, Taxes on fuel, lubricants or other consumable technical supplies, supra note 28, para. 2.

${ }^{30}$ See ICAO's Policies on Taxation in the Field of International Air Transport, Council Resolution on Taxation of International Air Transport, supra note 28 , para. 3.

31. See the French eco-tax on air tickets ("éco-contribution sur le transport aérien") introduced by Article 72 of Finance Law n'2019-1479 of 28 December 2019, modifying Article 302 bis K of the General Tax Code ('code general des impôts'). On air transport taxes, see Uwe Erling, 'The German Air Transport Tax: A Treaty Override of International Law' (2015) 10(2) FIU Law Review 467-92; CE Delft, A study on aviation ticket taxes, November 2018.

32. ICAO's Policies on Taxation in the Field of International Air Transport, supra note 28, introduction, para. 3.

33. ICAO's Policies on Taxation in the Field of International Air Transport, Commentary on Council Resolution, Taxes on the sale and use of international air transport, supra note 28, para. 14.

34. Ibid.

35. See the conclusions of the following report prepared for the European Commission: CE Delft, 'Taxes in the Field of Aviation and Their Impact' Final Report, June 2019.

36.In the 2002 supplement to Doc. 8632, only a few contracting states, including the Netherlands, had made references to environmental objectives. Seven contracting states have included such references. France, Sweden and the United Kingdom even explicitly refer to climate change.

37. ICAO's Policies on Taxation in the Field of International Air Transport, 3rd edtn, 2016, Supplement to Doc 8632, available at https://www.icao.int/publications/Documents/ 8632_cons_sup_en.pdf.

38. Ibid. 
polluting flights". ${ }^{39}$ Similarly, according to Norway, taxes on fuels might be justified in the context of policies aimed at protecting the environment. ${ }^{40}$

Yet, the approach of the ICAO is that taxes are not a good option for mitigating the environmental impact of the aviation sector. In 1996, in a specific resolution on environmental charges and taxes, the ICAO Council expressed its strong preference for environmental charges - which are supposed to cover the environmental costs of civil aviation - over environmental taxes - which generate "general national and local governmental revenues that are applied for non-aviation purposes." This distinction, which may seem artificial at first sight, suggests that the ICAO Council is against the adoption of environmental taxes when there is no guarantee that their proceeds will be reallocated to the aviation sector. In other words, what the ICAO calls an "environmental charge" is an earmarked environmental tax that is not aimed at generating revenue but rather at covering the environmental costs of the aviation sector. ${ }^{42}$ The ICAO Assembly has also issued more general statements on climate change, including on how it plans to address the climate impact of international civil aviation. ${ }^{43}$ In 2013, the ICAO Assembly voted in favor of the introduction of a global market-based mechanism (GMBM) for the aviation sector. ${ }^{44}$ This mechanism was set up in 2016 by the ICAO Assembly in the form of a Carbon Offsetting and Reduction Scheme for International Aviation (CORSIA). ${ }^{45}$ The scheme is supposed to enter into force, initially through a pilot phase, in $2021 .^{46}$

Given the move toward the adoption of a global, non-fiscal, market-based scheme, it is unlikely that the ICAO council will change its position on the taxation of the aviation sector. Similarly, it is highly unlikely that the Chicago Convention and bilateral air agreements will be renegotiated in the foreseeable future. ${ }^{47}$ Countries that would introduce environmental taxes on aviation fuel would, therefore, do so in opposition to the rest of the international community. To the extent that these taxes are aimed at mitigating climate change, they could also violate Article 2(2) of the Kyoto Protocol, which states that "the Parties (...) shall pursue limitation or reduction of emissions of greenhouse gases not controlled by the Montreal Protocol from aviation and marine bunker fuels, working through the International Civil Aviation Organization and the International Maritime Organization, respectively." 48 Moreover, countries would face opposition from the International

\footnotetext{
${ }^{39}$ Ibid.

40. Ibid. Norway has taxed fuel on domestic flights since 1999. It has informed the ICAO that "Tax policy in respect of environmental protection may be a reason for introducing taxes on fuel for the use by aircrafts in general."

41. Council Resolution on Environmental Charges and Taxes adopted by the Council on 9 December 1996 at the 16 th Meeting of its 149th Session, available at https://www.icao.int/sustainability/Pages/eap-im-levies.aspx.

42.Ibid. On this distinction, see also OECD, Special Issues in Carbon/Energy Taxation: Marine Bunker Fuel Charges, Annex I Expert Group on the United Nations Framework Convention on Climate Change, Working Paper No. 12, OCDE/GD(97)78, at 24, available at http://www.oecd.org/officialdocuments/publicdisplaydocumentpdf/?cote=OCDE/GD(97)78\&docLanguage=En. 43. Resolution A37-19, Consolidated Statement of Continuing ICAO Policies and Practices Related to Environmental ProtectionClimate Change, available at https://www.icao.int/sustainability/Documents/A37-Env-Resos-9958.pdf.

44. Resolution A18-18 ICAO, Consolidated Statement of Continuing ICAO Policies and Practices Related to Environmental Protection-Climate Change, para. 18, available at https://www.icao.int/sustainability/Documents/A38-Res_10022_en.pdf.

45. See Resolutions A39-1 ICAO, Consolidated Statement of Continuing ICAO Policies and Practices to Environmental Protection-General Provisions, Noise and Local Air Quality; A39-2 Consolidated Statement of Continuing ICAO Policies and Practices Related to Environmental Protection-Climate Change and Resolution A39-3 Consolidated Statement of Continuing ICAO Policies and Practices Related to Environmental Protection Global Market-Based Measure (MBM) Scheme [hereinafter Resolution A39-3]. These resolutions supersede resolutions A38-17 and A38-18. See supra Resolution A39-3, point 1.

46. See Resolution A39-3, note 45, point 9.

47. The situation has not changed since Keen and Strand published their article. They stated: "Given the diversity of countries' views on the desirability of taxing aviation fuel and the potential for opening up a still wider set of issues, renegotiating the Chicago Convention appears currently out of the question." Keen and Strand, supra note 27, at 11.

48.In the context of E.U. law, the legal effect of this provision seems, however, very limited. See CJEU, Air Transport Association
} 
Air Transport Association (IATA), which — in the same way as representative organizations of the shipping and aviation industries in the 1920s-has an influential role in the design of regulations affecting the aviation sector. ${ }^{49}$

In any case, if the CORSCIA is successful in mitigating the climate contribution of the aviation sector, environmental taxes might become redundant. This illustrates that taxes are only one instrument among many for internalizing environmental costs. If the CORSCIA is not successful, however, a revision of the Chicago Convention and bilateral air agreements might be necessary so as to explicitly allow countries to internalize the environmental costs of the aviation sector through their tax system.

\section{B. Taxes on the Profits of International Air Transport}

Legal limits do not only apply to the (indirect) taxes that can be imposed on aviation fuel but also to the direct taxes imposed on aviation transport in cross-border situations. ${ }^{50}$ Double tax treaties can regulate the way that profits derived from international air transport are being taxed. Under double tax treaties based on Article 8 of the OECD and U.N. Model Tax Conventions, these profits will be taxable in the country of residence of the enterprise operating the ships or aircraft. ${ }^{51}$ The same principle applies to the taxation of gains derived from the alienation of aircrafts (Article 13, para. 3 of the OECD/U.N. Models) and to the taxation of capital of an enterprise operating aircraft in international traffic (Article 22, para. 3 of the OECD/U.N. Models).

In addition to the OECD and U.N. Models, the ICAO also supports taxation in the country of residence. Indeed, the ICAO resolution on the taxation of the income of international air transport enterprises encourages ICAO members to grant reciprocal "exemption from taxation on the income of air transport enterprises of other Contracting States derived in that Contracting State from the operation of aircraft in international air transport." ${ }^{2}$ The resolution invites ICAO members to grant such reciprocal exemptions either through the negotiation of bilateral agreements or, preferably since it is the easiest option, through the adoption of legislation at the domestic level. ${ }^{53}$

\footnotetext{
of America and Others, 21 December 2011, C-366/10, paras. 73-78, where the Court of Justice considered that the Kyoto Protocol had no direct effect.

49. The IATA is clearly opposed to green taxes. See IATA, Fact Sheet, "Green" Taxes, May 2018, available at https://www.iata.org/pressroom/facts_figures/fact_sheets/Documents/ fact-sheet-greentaxation.pdf. See also Letter to the Ministry of Finance of the Netherlands regarding the Dutch Air Passenger Tax, available on the website of the European Regions Airline Association at https://www.eraa.org/system/files/industry_letter_on_dutch_aviation_taxation_policy_23nov2017_0.pdf.

50.The taxation of the profits of the international aviation sector is complex. This section simply aims at highlighting that States might be restricted in the way they impose taxes on the profits of international airlines companies.

51. See article $8, \S 1$ of the OECD Model Convention. The same wording is used in article 8 (Alternative A), $\S 1$ of the United Nations Model Double Taxation Convention Between Developed and Developing Countries, 2017. Please note, however, that article 8 (Alternative B) of the OECD Model does not apply residence taxation to profits derived from the shipping sector when shipping activities in the source country are "more than casual." Article 8 (alternative B), $\S 2$. Article 8 of the OECD and U.N. Models was modified in 2017 on the basis of treaty practices: instead of being taxed in the country of the "place of effective management" of the enterprise, profits are now taxed in the "State of the enterprise." See Commentary on Article 8, OECD Model, paragraph 1, sections 1 and $2(\mathrm{C}(8)-1)$. The same modification has been included in the U.N. 2017 Model. See also commentary on Article 8 (alternatives A and B) of the United Nations Model Double Taxation Convention between Developed and Developing Countries, section 5, at 239, available at https://www.un.org/esa/ffd/wp-content/uploads/2018/05/MDT_2017.pdf.

52. See ICAO's Policies on Taxation in the Field of International Air Transport, Council Resolution on Taxation of International Air Transport, supra note 28. In particular, see para. 2, (a) (i).

53.Ibid., para. 2, c) and para. 12 of the Commentary. For example, Belgium implements this clause through its income tax code and bilateral tax treaties; the United Kingdom implements this clause through bilateral air services agreements. See also ICAO's Policies on Taxation in the Field of International Air Transport, 3rd edn (2016), Supplement to Doc. 8632.
} 
Double tax treaties that follow the OECD/U.N. Models and the recommendations of the ICAO seem favorable to the aviation sector. Taxation in the country of residence simplifies the tax treatment of the sector. The shipping sector aside, other international transport sector do not benefit from the same tax treatment or, at least, not to the same extent. ${ }^{54}$ Combined with the absence of taxes on aviation fuel, this special treatment could, potentially, distort passengers' choices by incentivizing them to either fly more than they would if costs were higher and/or to favor aviation over less polluting modes of transport (e.g., rail transport) if the relative tax advantage from which the aviation sector benefits is passed on to consumers. ${ }^{55}$ Empirical work would be necessary to assess whether, how and to what extent the provisions in double tax treaties that apply to the aviation sector may indirectly influence consumers' choices. International aviation and other transport means might not always be substitutable and comparable, given the many practical differences that characterize the way these sectors operate ${ }^{56}$ Moreover, in addition to taxes on fuel and income, one would need to take into account other relevant taxes and charges that could also affect consumer's choices (e.g., VAT, ticket taxes, airport fees, and registration taxes).

Questions arise with respect to the reasons underlying the specific tax treatment granted to the aviation sector in the OECD and U.N. Model Tax Conventions. Justifications can be found in the history of the Models. In order to support the rule of reciprocal exemption, some negotiators referred to the special character of the shipping and aviation sectors. ${ }^{57}$ This argument is not fully convincing: the international character of the shipping and aviation sectors do not pose fundamentally different problems to other cross-border activities, which nevertheless do not benefit from the same reciprocal exemption. ${ }^{58}$ The fact that a journey can take place over many jurisdictions, which could lead to fragmented taxation, is not specific to air transport or shipping but instead generally characterizes international transport.

Another, more political and practical, explanation for the preferential treatment granted to the shipping and aviation sectors lies in the important role played by the League's Transit Commission,

54. Please note that the U.N. Model mentions the possibility for countries to extend the provisions of article 8 to rail or road transport. See Commentary on Article 8, A. General Considerations, section 7, at 240: "Depending on the frequency or volume of cross-border traffic, countries may, during bilateral negotiations, wish to extend the provisions of Article 8 to cover rail or road trans port. (...)" Interestingly, the need to protect a level playing field between the aviation sector and other sectors is often mentioned in documents of the ICAO. See, e.g., Annex of ICAO Assembly 39-2, point (h): "MBMs [market-based mechanisms] should ensure the fair treatment of the international aviation sector in relation to other sectors." See also Georg Kofler, "Article 8 (Shipping, Inland Waterways Transport and Air Transport)' [hereinafter Kofler, 'Article 8 (Shipping, Inland Waterways Transport and Air Transport)'] in Ekkehart Reimer and Alexander Rust (eds), Klaus Vogel on Double Taxation Conventions (Wolters Kluwer, 2015) 535-76, at 571 (on the extension of the residence principle to road and railway transport).

55.Keen, Parry and Strand, supra note 27 (pointing to the impact that the favorable corporate income tax regime on the shipping sector could have on investors: it could "encourage entry, meaning a misallocation of capital toward shipping and away from other activities and, once again, both a loss of revenue and a tax bias toward higher sectoral output - and emission."

56.The question as to whether the exemption of the aviation transport from fuel taxes was discriminatory against rail transport undertakings has been analyzed under E.U. law. See Court of First Instance, Deutsche Bahn AG v. Commission of the European Communities, 5 April 2006, T-351/02, para. 138.

57. Sunita Jogarajan, Double Taxation and the League of Nations (CUP 2018), at 46-7 and 216-22. This is a very common argument used by the ICAO. See, e.g., ICAO's Policies on Taxation in the Field of International Air Transport, supra note 28, introduction, para. 1. All the documents related to the ICAO's policies on taxation can be found via the following webpage: https://www.icao.int/publications/pages/publication.aspx?docnum=8632. See also Kofler, 'Article 8 (Shipping, Inland Waterways Transport and Air Transport,' supra note 54, at 549; Georg Kofler, 'Article 8 OECD Model: Time for a Change ?' in Guglielmo Maisto (ed), Taxation of Shipping and Air Transport in Domestic Law, EU Law and Tax Treaties (IBFD, 2017) 129-48.

58. Guglielmo Maisto, "Chapter 3. Shipping, Inland Waterways Transport and Air Transport (Article 8 OECD Model Convention) [hereinafter Maisto, 'Chapter 3'] in Michael Lang, Pasquale Pistone, Josef Schuch and Claus Staringer (eds), Source Versus Residence. Problems Arising from the Allocation of Taxing Rights in Tax Treaty Law and Possible Alternatives (Kluwer Law International, 2008) 21-57, at 33. See also Jogarajan, supra note 57, at 46-47; Kofler, 'Article 8 (Shipping, Inland Waterways Transport and Air Transport),' supra note 53, § 8.3.3. 
the International Shipping Conference, the ICAO in the negotiations of the 1928 Model Tax Treaties on Double Income Taxation. ${ }^{59}$ These groups argued that past States' practices supported the rule of reciprocal exemption because some countries had already granted exemption to the shipping sector in their bilateral tax treaties. ${ }^{60}$ Regarding the aviation sector, the exemption was described as a logical proposal, considering the subsidized character of the aviation industry and the benefits that airlines could bring to countries. ${ }^{61}$ As Jogarajan puts it: "It was inconceivable that any country would want to tax the government subsidies paid to airlines. Further, countries that did not have an airline derived great benefits from the airline services of other countries." 62

Aside from these arguments, Maisto considers that the specific treatment granted to the shipping and aviation industries might be explained by the special geographical space in which these sectors operate. ${ }^{63}$ In contrast to road transport, aviation and shipping activities can take place in a geographical place that is not always "physically located in the territory of a State," navigating non-territorial waters and international airspace. ${ }^{64}$ This practical difference might have explained why the taxation of these two sectors was explicitly addressed by the League of Nations, where road transport was disregarded.

Today, however, these historical reasons might no longer justify the different, arguably preferential, treatment applied to the aviation and shipping sectors in comparison to other crossborder transport activities. ${ }^{65}$ From an environmental perspective, differential tax treatment should ideally rely on environmental justifications. The differentiated regime that currently applies to the aviation sector cannot be justified on such grounds.

\section{INTERNATIONAL TAX LAW AS A POTENTIAL OBSTACLE TO THE DEVELOPMENT OF NEW ENVIRONMENTAL TAXES: THE EXAMPLE OF ENVIRONMENTAL BORDER TAX ADJUSTMENTS}

As mentioned before, countries' tax sovereignty might be limited by provisions of international (tax) law. ${ }^{66}$ This section sheds light on the legal and political role of international tax provisions in shaping a narrative about the domestic tax measures considered to be acceptable for tackling global environmental issues and those that are not, due to their controversial character under international tax/trade law. To a large extent, it seems that environmental tax measures become controversial as soon as their scope of application is extended to internationally traded goods and services. This section focuses on tax-related provisions in WTO agreements, in particular the GATT and the

\footnotetext{
59. Jogarajan, supra note 57, at 216, 221 and 246. See also Sunita Jogarajan, 'The 'Great Powers' and the Development of the 1928 Model Tax Treaties' in Peter Harris and Dominic De Cogan (eds), 8 Studies in the History of Tax Law (Hart, 2017) 341-362, at 351; Guglielmo Maisto, 'The History of Article 8 of the OECD Model Treaty on Taxation of Shipping and Air Transport' (2003) 31(6/7) Intertax 223, at 236 and at 238-39 and 243 [hereinafter Maisto, 'The History of Article 8']. See also R.I.R. Abeyratne, 'Taxation in the Field of International Air Transport_Legal Aspects' (1991) 16(3) Air and Space Law 106-17, at 108. 60. Maisto, 'Chapter 3,' supra note 58; Maisto, 'The History of Article 8,' supra note 59, at 234 (referring to the 1923 Convention between Hungary and Czechoslovakia).

61. Jogarajan, supra note 57, at 222.

62. Ibid.

63. Maisto, 'The History of Article 8,' supra note 59, at 236.

64. Ibid. at 236 and 244 .

65.Maisto, 'Chapter 3,' supra note 57, at 35. In his analysis of article 8 of the OECD Model, Maisto comes to the conclusion that there are "No conceptual reasons to exclude railway and road transportation" from the benefit of this provision. The other way of looking at article 8 would be to argue that there are no conceptual reasons to maintain the benefit of this provision to the shipping and aviation sector.

66. See supra Section III.
} 
ASCM, using environmental BTAs as an example to highlight how these tax provisions might function as obstacles to the adoption of tax regimes with an extended territorial scope, including adjustments for imported and exported products.

As explained above, the unilateral adoption of environmental taxes is problematic when it affects competitiveness and encourages domestic enterprises to relocate to jurisdictions with less restrictive environmental standards. ${ }^{67}$ One option to alleviate these disadvantages is the adoption of environmental BTAs. ${ }^{68}$ Environmental BTAs help to create a level playing field between domestic and foreign enterprises/products. In the context of climate change, the idea underlining such adjustments on imports is to impose the same carbon tax on imported products as the one applied-directly or indirectly-to domestic products. On the export side, the idea is to relieve exported products of domestic carbon taxes. So far, most legislative proposals in favor of such environmental adjustments have never made it into law, possibly because the design of domestic taxes aimed at mitigating global environmental issues is complex, ${ }^{69}$ but possibly also because environmental BTAs are considered incompatible with tax-related provisions in WTO law agreements. $^{70}$

There is a broad literature that discusses the compatibility of environmental BTAs with WTO agreements. ${ }^{71}$ It is unclear whether international trade law prevents their adoption, but many scholars have come to the conclusion that they are at risk of violating the tax specific provisions that are part of the General Agreement on Tariffs and Trade (GATT) and the Agreement on Subsidies and Countervailing Measures (GATT). ${ }^{72}$

Under the GATT, Articles II:2(a) and III:(2) regulate the adoption of discriminatory taxes on imported products. One of the main controversial questions in the literature relates to whether these provisions prevent the adoption of taxes that differentiate between products on the basis of nonproduct related process and production methods (PPMs). Carbon BTAs fall into this category. On the import side, carbon BTAs would subject imported products to differentiated taxes based on

67. See supra Section II.

68. IMF, Fiscal Monitor Report, supra note 10, p. 20, table 1.6 (giving a clear overview of the available options that countries might consider to alleviate the risk of loss of competitiveness for trade-exposed firms).

69. See supra section II.

70.The U.S. taxes on petroleum and certain imported substances discussed in the Superfund case offer one rare concrete example of environmental BTAs that made it into law. GATT, Panel Report, United States-Taxes on Petroleum and Certain Imported Substances, Report adopted on 17 June 1987, L/6175, 34S/136.

71.See, among others, Kateryna Holzer, Carbon-related Border Adjustment and WTO Law (Edward Elgar Publishing, 2014); Michael A. Mehling et al., 'Designing Border Carbon Adjustments for Enhanced Climate Action' (2019) American Society of International Law 433-81; Pirlot, supra n. 3.

72.The next paragraphs briefly summarize the legal arguments surrounding this question, building upon the existing literature on border carbon tax adjustments. They are largely based on my book, which includes extensive references to the existing literature. Pirlot, supra n. 3. Among the numerous articles and books on the topic, see Carol McAusland and Nouri Najjar, 'The WTO Consistency of Carbon Footprint Taxes' (2015) 46(3) Georgetown Journal of International Law 765-801; Felicity Deane, Emissions Trading and WTO Law. A Global Analysis (Edward Elgar Publishing, 2015), in particular chapter 7; Paul Demaret and Raoul Stewardson, 'Border Tax Adjustments Under GATT and EC Law and General Implications for Environmental Taxes' (1994) 28(4) Journal of World Trade 5-66; Olivier De Schutter, Trade in the Service of Sustainable Development. Linking Trade to Labour Rights and Environmental Standards (Hart Publishing, 2015), in particular chapter 3; Kateryna Holzer, Carbon-Related Border Adjustment and WTO Law (Edward Elgar Publishing, 2014); Gary Clyde Hufbauer, Steve Charnovitz and Jisun Kim, Global Warming and the World Trading System (Peterson Institute for International Economics 2009); Charles E. McLure, 'The GATTLegality of Border Adjustments for Carbon Taxes and the Cost of Emissions Permits: A Riddle, Wrapped in a Mystery, Inside an Enigma' (2011) 11 Florida Tax Review 221-94; Joost Pauwelyn, 'Carbon Leakage Measures and Border Tax Adjustments Under WTO Law' in Geert Van Calster and Denise Prévost (eds), Research Handbook on Environment, Health and the WTO (Edward Elgar Publishing, 2013), 448-506; Geert Van Calster, International and EU Trade Law. The Environmental Challenge (Cameron May, 2000) 414-85; Richard A. Westin, Environmental Tax Initiatives and Multilateral Trade Agreements: Dangerous Collisions (Kluwer Law International, 1997). 
how much GHG emissions have been released during their production process so as to equalize the tax borne by domestic products. Consequently, if GATT provisions regulating BTAs on imports prohibit differentiation based on non-product related PPMs, carbon BTAs would necessarily be found incompatible with the GATT ${ }^{73}$ Although there are convincing arguments to oppose this view, it is hard to anticipate whether the WTO dispute settlement body would interpret the tax provisions in the GATT in a non-restrictive way to allow for the adoption of carbon BTAs.

In addition to the GATT, carbon BTAs that include adjustments on exports are subject to the ASCM, which regulates the use of subsidies. As for carbon BTAs on imports, it is unclear whether environmental BTAs on exports would violate the ASCM or not. The literature is divided, and the debate will remain, unless a concrete case is brought in front of the WTO dispute settlement body. Although it is difficult, if not impossible, to determine whether the absence of carbon BTAs is due to the legal uncertainty surrounding their adoption, it is undeniable that WTO law has often been used as an argument against the introduction of such measures. To a large extent, environmental BTAs seem much less acceptable than other types of measures also aimed at alleviating the economic and environmental risks linked to the adoption of unilateral environmental policies. For example, many countries have adopted exemption regimes in favor of the sectors that face high competitive pressure and that would be the most affected by domestic carbon taxes or emissions trading schemes. ${ }^{74}$ Though they have not been challenged, these exemption regimes could also infringe some WTO law provisions (in particular those on subsidies). ${ }^{75}$ This suggests that double standards in the interpretation of WTO law are used to determine which environmental tax measures are acceptable (namely those, as exemptions, that do not seem to have cross-border effects) and those which are not (namely those, as environmental BTAs, that explicitly apply to imports and exports). In other words, the example of environmental BTAs illustrates how international tax law provisions might be interpreted in a restrictive way so as to provide arguments against the adoption of new types of environmental tax measures. In this case, international tax provisions do neither cause pollution nor justify past inconsistencies in domestic tax systems with respect to today's environmental concerns. Rather, they prevent the future development of tax systems that meet today's environmental challenges.

\section{INTERNATIONAL TAX LAW AS A POTENTIAL OBSTACLE TO THE EFFECTIVENESS OF ENVIRONMENTAL REGULATIONS: THE EXAMPLE OF EMISSIONS TRADING SCHEMES}

In addition to the obstacles that international tax provisions create for internalizing the

73. Unless they are justified under GATT general exception provision (GATT article XX). This question is analyzed in detail in Pirlot, supra n. 3.

74. Exemptions are not only used in respect of carbon taxes but also in respect of other market-based mechanisms, such as the European Union Emissions Trading Scheme (E.U. ETS). An overview of concrete examples of carbon taxes and their related exemption regimes can be found in Committee of Experts on International Cooperation in Tax Matters, 17-20 October 2017, Environmental Tax Issues of Relevance to Developing Countries, supra note 16. Gilbert E. Metcalf considers that exemptions are one of the pitfalls to be avoided in the design of carbon taxes because it will "dilute the carbon price signal." Gilbert E. Metcalf, Paying for Pollution, Why a Carbon Tax is Good for America (OUP, 2019) 112.

75. In the context of the E.U. ETS, see Deane, supra note 71, chapter 6 "The subsidies of emissions trading schemes"; Kateryna Holzer, WTO Law Issues of Emissions Trading (2016) 1 Working Paper World Trade Institute and NCCR Trade Regulation, available at https://core.ac.uk/download/pdf/44740970.pdf; Ingrid Jegou and Luca Rubini, 'The Allocation of Emission Allowances Free of Charge: Legal and Economic Considerations' (Transition to a Low Carbon Future Series) Issue Paper 18 (2011); International Centre for Trade and Sustainable Development, available at https://www.ictsd.org/sites/default/files/downloads/2011/08/the-allocation-of-emission-allowances-free-of-charge.pdf. 
environmental costs of polluting activities through the domestic tax system, ${ }^{76}$ international tax law might affect the effectiveness of non-fiscal market-based instruments. Indeed, double tax treaties can have an impact on environmental regulations that create new sources of "income" (e.g., environmental regulations creating emissions rights or biodiversity conservation credits that have a market value). Uncertainty regarding the cross-border fiscal treatment of these new sources of income could affect the effectiveness of any new environmental regime put in place. Such undesirable frictions between environmental and tax law will mostly affect "economic" (marketbased) environmental regulations. ${ }^{77}$ Frictions could appear in the form of double taxation, which would change the price signal at the base of the environmental regulation. Similarly, double nontaxation or uncoordinated tax regimes could push taxpayers into internalizing environmental costs in the "cheapest" way possible, which is desirable at the domestic level but could impact on the effectiveness of environmental regulations in a cross-border context. ${ }^{78}$ Non-economic (so-called "command and control") instruments are likely to remain unaffected by international tax provisions, because they do not create new sources of income that can be subject to taxation.

This section analyzes this third negative effect of international tax law on environmental protection by focusing on one category of environmental market-based instruments, namely the emissions trading schemes. These schemes are often considered as an alternative to carbon taxes. ${ }^{79}$ They are aimed at internalizing the costs of GHG emissions by requiring energy-using economic operators (e.g., power stations, industrial plants, airlines) to surrender emissions permits that correspond to the level of GHG emissions they generate. These allowances can be traded, which implies that they can become a source of income. Moreover, as soon as two national or regional trading schemes are linked together, emissions allowances will be transferred from one company to another, across countries.

Past literature suggests that the tax implications derived from the cross-border application of emissions trading schemes could affect their effectiveness. ${ }^{80}$ Initially, there was uncertainty as to how such instruments might be treated under double tax treaties. ${ }^{81}$ Subsequently, the United Nations and the OECD clarified the tax treatment that applies to the cross-border transfer of

76.See supra Sections III and IV.

77. On the definition of market-based instruments, see Richard B. Steward, 'Instrument Choice' in Daniel Bodansky, Jutta Brunnée, and Ellen Hey (eds), The Oxford Handboook of International Environmental Law (OUP, 2008), 148-81.

78.See Ethan Yale, 'Taxing Cap-and-Trade Environmental Regulation' (2008) 37(2) Journal of Legal Studies, 535-50, at 536. See also Carolyn Fischer, 'Multinational Taxation and International Emission Trading' (2006) 28 Resource and Energy Economics 13959.

79. Note however that it is not always clear whether emissions trading schemes always differ from tax measures. See, e.g., the discussions on the tax nature of the E.U. emissions trading schemes. Advocate General Kokott, Opinion in Air Transport Association of America and Others, C-366/10, 6 October 2011, paras. 214-15). See also Alice Pirlot, 'Exploring the Impact of EU Law on Energy and Environmental Taxation' in Christiana Panayi, Werner Haslehner, Edoardo Traversa (eds), Research Handbook in European Union Taxation Law (Edward Elgar Publishing, 2020), available at https://www.e-elgar.com/shop/research-handbookon-eu-tax-law, $\S 2.2$.

80. Regarding the tax effects of linking emissions trading schemes, see the literature mentioned in Celeste M. Black, 'Taxation of Cross-Border Transfers of Carbon Emission Allowances under Linked Emissions Trading Schemes' (2017) 6(2) Transnational Environmental Law, 335-61, at 337. She refers inter alia to Mitchell A. Kane, 'Taxation and Multi-Period Global Cap and Trade' (2011) 19(1) N.Y.U. Environmental Law Journal 87-145 and Fischer, supra note 78.

81. Black, Ismer and Haussner analyzed these issues. Black, supra note 80; Roland Ismer and Manuel Haussner, 'Emissions Trading and Tax Treaties' (2015) 69(8) Bulletin for International Taxation 8. See also Katalin Csikós, 'International Tax Implications of Tradable Allowances' (2007) 47(3) European Taxation 135-43. This topic was also touched upon during one of the seminars of the 67th IFA Congress organized in Copenhagen focused on climate change and international taxation. See IFA 67th Congress in Copenhagen-Seminar A: Climate Change and International Taxation (26 Aug. 2013), News IBFD (accessed 27 Aug. 2019 )). Authors also analyzed the question at the domestic level. See Isabelle Richelle, 'Emission Trading: Accounting and Tax Regime in Belgium' (2008) Bulletin for International Taxation 414-21. 
emissions allowances between companies under their respective tax treaty models. ${ }^{82}$ In principle, if countries follow the proposed changes to the OECD commentary, income derived from the issuance or the trading of emissions allowances will qualify either as business profits (Article 7 of the OECD Model) or capital gains (Article 13 of the OECD Model). ${ }^{83}$

Yet, some uncertainties remain. Countries that decide to link their emissions trading scheme might not be treaty partners. Moreover, they may have special domestic tax regime on emissions allowances, which could lead to distortions between the issuance and trading of allowances at the domestic and bilateral level. By analyzing Australia's tax regime for carbon trading, Black provides a detailed overview of how transfers of allowances would be taxed and points to the potential situations of double taxation that could arise if the countries participating to the linking of their schemes do not coordinate. She concludes that tax outcomes should be anticipated for any emissions scheme linking proposals in order to make sure that international tax supports the environmental goal underlying the linking proposals:

This [modelling of tax outcomes] could test for any inconsistencies in tax consequences under the specific features of the tax legislation of the linking partners and the proposed linking mechanism. If significant impacts are identified, rather than being seen as a barrier to linking, this would signal a need to reform the tax regime to support the linking mechanism. ${ }^{84}$

Black's conclusion highlights the key effects that international taxation might have on environmental market-based instruments when their implementation involves cross-border transactions. Environmental instruments are more effective when they are implemented on a larger scale than the national territory. But a lack of tax coordination - and the risk of double taxationcould be a barrier to the adoption of market-based instruments at the bilateral or regional level. From this perspective, clear tax rules on how taxation applies to environmental market-based instruments in cross-border situations can be one avenue for international tax law to be supportive of environmental policies.

\section{CONCLUSION}

The fields of international tax and environmental law pursue very different objectives and they could therefore appear to be inherently independent from each other. However, as this Chapter has shown, these fields do interact. Tax provisions in tax and non-tax-specific international agreements can both undermine and/or support the objective of mitigating global environmental challenges.

First, international tax law could "become" environmental law if global environmental taxes or international models of environmental taxes were to be adopted (section II). However, although the role of taxation in supporting environmental objectives has been explicitly acknowledged in

82. OECD Committee on Fiscal Affairs on 26 June 2014, Tax Treaty Issues Related to Emissions Permits/Credits. See also UN, Committee of Experts on International Cooperation in Tax Matters, 8th session, United Nations Model Convention and climate change mechanisms, Note on tax treaty issues arising from the granting and trading of emissions permits and emissions credits under the U.N. Model Tax Convention, 28 September 2012, E/C.18/2012/CRP.6.

83. New paragraph 75.1 to the Commentary on Article 7 OECD Model.

[I]income derived from the issuance or trading of emissions permits and credits is generally covered by Article 7 and Article 13 . Under certain circumstances, however, such income may be covered by Article 6, 8, or 21 (see paragraph 2.1. of the Commentary on Article 6 and paragraph 14.1. of the Commentary on Article 8).

Ibid.

84. Black, supra note 80, at 361. See also Andrei Cracea, 'Direct Tax Treatment of Greenhouse Gas Emission Allowances within the European Union' (2012) 52(12) European Taxation 571-78, at 578. 
the context of the United Nations Sustainable Development Goals, international tax law has not yet become environmental law. No global environmental tax or tax model has been adopted so far. ${ }^{85}$ International tax law should not be blamed: the main obstacle to the international use of taxation to mitigate global environmental issues is political rather than legal.

Yet, in certain circumstances, there might be good reasons to "blame" the international tax regime for the negative role it plays in countries' environmental legal framework. By means of three concrete examples, this Chapter has shed light on how international tax law might have negative effects on environmental protection. In certain cases, international tax law prevents or discourages countries from amending their tax system so as to internalize the environmental costs of certain sectors or, simply, avoid distortive effects that encourage polluting behaviours. In other cases, legal uncertainty surrounding the interpretation of some international tax provisions possibly causes countries to refrain from adopting new types of tax measures aimed at internalising pollution costs. Finally, international tax law, in particular double tax treaties, sometimes affect the effectiveness of environmental market-based regulations.

Therefore, the question arises as to what can be done to alleviate these potential negative effects. Tax reforms might be necessary when international tax law has a direct and clear impact on environmental protection. However, the need for tax reform should not be overestimated. First, tax is not the only tool available to protect the environment; other market-based and non-market-based instruments can be used. For example, if a global emissions scheme is effective in mitigating the emissions of the aviation sector, the impact of tax treaties and the Chicago Convention might no longer be considered problematic. Second, in some cases, the obstacles created by international tax provisions are unclear and possibly non-existent. For example, international tax provisions in trade agreements could be interpreted in a non-restrictive way so as to allow for the adoption of environmental BTAs. Reforms might be excessive in those cases; it might be sufficient to clarify the interpretation of the law to highlight that it does not prevent the adoption of innovative environmental tax measures. Third, there is no need for tax reform when the negative impact of international tax law can easily be avoided by anticipating the tax consequences linked to the adoption of environmental market-based instruments.

Therefore, rather than a call for international environmental taxes, this Chapter is a call for better coordination between international tax and environmental law. First, the existing interactions between international tax and environmental law need to be acknowledged. It is not correct to regard them as disconnected from each other, and this can lead to undesirable outcomes. Second, the interactions between these two fields need to be further researched. With the reform of the international tax system undertaken by the OECD/G20, new questions emerge. Indeed, the implementation of the OECD/G20 Base Erosion and Shifting Project (BEPS) could have distortive economic effects, which, in some cases, might be coupled to unintended negative environmental consequences, for example by encouraging the relocation of real activities to jurisdictions with low tax and low environmental standards. ${ }^{86}$ Reporting rules on multinational corporations that include

85. On the interactions between taxation and the U.N. SDGs, see Allison Christians, 'Aligning Tax Rules with Sustainable Development: Why and How' (2019), to be published. See also Alice Pirlot, 'A Legal Analysis of the Mutual Interactions between the U.N. Sustainable Development Goals (SDGs) and Taxation' in Cécile Brokelind and Servaas van Thiel (eds), Tax Sustainability in the EU and International Context, IBFD (2020), 87-111.

86. Favorable tax jurisdictions might also be "pollution haven" in their own rights, namely jurisdictions with low environmental standards. Gillepsie notes that the relocation of pollution intensive industries to developing countries in the 1990s "appears to have been attributable to combinations of lower wages, lower labor standards, ease of trade and access to markets, the costs of transport, the price of land, taxation advantages and lower environmental standards.” Alexander Gillepsie, The Long Road to Sustainability: 
non-financial information could help in assessing these potential negative effects. If necessary, measures should be introduced to avoid the indirect polluting effects that may be caused by international tax reforms.

\section{LIST OF MOST IMPORTANT REFERENCES (BY ALPHABETICAL ORDER)}

Bilbao Estrada, Iñaki and Pistone, Pasquale, 'Global CO2 Taxes' (2013) 41(1) Intertax 2-14.

Cuervo, Javier and. Gandhi, Ved P, 'Carbon Taxes: Their Macroeconomic Effects and Prospects for Global Adoption-A Survey of the Literature' (1998) IMF Working Paper

Falcão, Tatiana, A Proposition for a Multilateral Carbon Tax Treaty (IBFD, 2019).

Ismer, Roland and Haussner, Manuel, 'Emissions Trading and Tax Treaties' (2015) 69(8) Bulletin for International Taxation.

Keen, Michael, Parry, Ian and Strand, Jon, 'Planes, Ships and Taxes: Charging for International Aviation and Maritime Emissions’ (2013) 28(76) Economic Policy, 701-49.

Maisto, Guglielmo (ed), Taxation of Shipping and Air Transport in Domestic Law, EU Law and Tax Treaties (IBFD, 2017).

Mehling, Michael A. et al., 'Designing Border Carbon Adjustments for Enhanced Climate Action' (2019) American Society of International Law 433-81.

Pirlot, Alice, Environmental Border Tax Adjustments and International Trade Law (Edgar Elgar Publishing, 2017).

Thalmann,Philippe, 'Global Environmental Taxes' in Janet E. Milne and Mikael Skou Andersen (eds), Handbook of Research on Environmental Taxation (Edgar Elgar Publishing, 2012) 456-76.

The Past, Present, and Future of International Environmental Law and Policy (OUP, 2018) 152. 